\title{
Assessment of the Awareness, Perception, Attitudes, and Preparedness of Health-care Professionals Potentially Exposed to COVID-I 9 in the United Arab Emirates
}

This article was published in the following Dove Press journal:

Journal of Multidisciplinary Healthcare

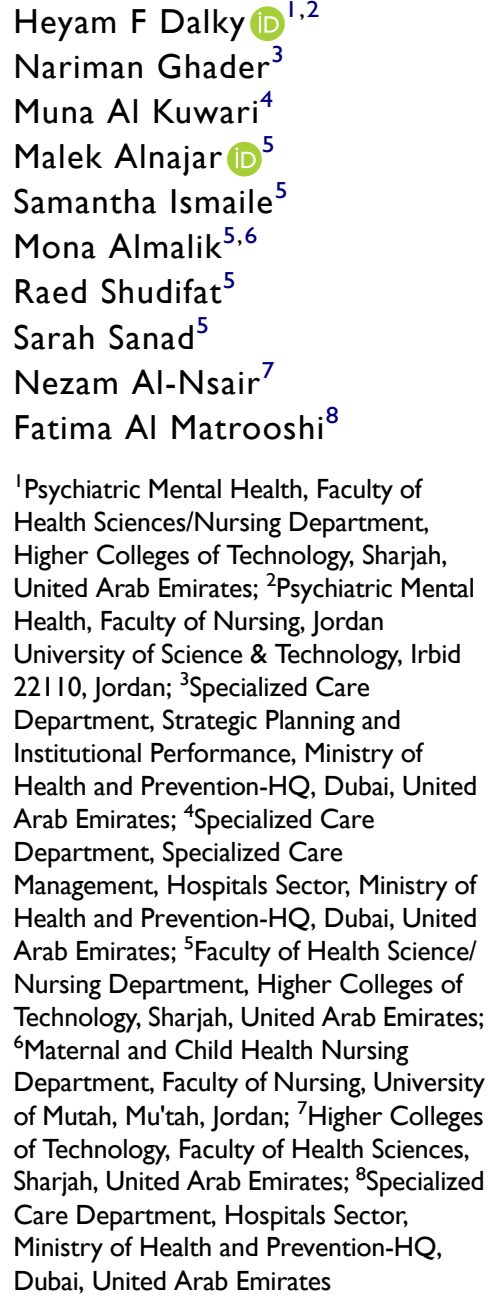

Correspondence: Heyam F Dalky Psychiatric Mental Health, Faculty of Health Sciences/Nursing Department, Higher Colleges of Technology, PO Box 9747, Sharjah, United Arab Emirates Email hdalky@hct.ac.ae
Background: Since COVID-19 surfaced in December 2019, health-care organizations across the globe have struggled to maintain the safety and well-being of health-care professionals (HCPs).

Purpose: This study investigates the HCPs' general understanding of the health risks of COVID-19 and to what extent they are equipped with the knowledge to protect themselves and others against this contagion.

Methods: This cross-sectional study used a web-based structured questionnaire posted on the UAE government electronic survey portal. A collection of 941 HCPs from diverse general and specialty hospitals in the UAE responded to an electronic participation invite.

Results: Our analysis showed that the majority of HCPs (97.6\%) had updated information about COVID-19 modes of transmission, risks of contamination, high-risk groups, and the potential consequences of testing positive. Furthermore, the results of the chi-squared testing revealed that the HCPs' confidence and vigilance of the COVID-19 threats were significantly increased $(p<0.01)$ by being experienced, having had infection control training, or/and having undergone COVID-19 education.

Conclusion: We conclude that HCPs have an evidence-based understanding of the ways their own health is at risk while they are performing their duties in hospital setups. Further, the study found that HCPs who undergo special infection control training and who are kept posted on the official updates on COVID-19 are more likely to remain vigilant at all times to minimize the risks to themselves and their patients. Although the generalizability of the study findings should be considered with caution, the results could be generalizable to health-care professionals who received similar COVID-19 related training in the UAE or other regional countries.

Keywords: vigilance, pandemic, attitude, COVID-19, infection control, health-care professionals

\section{Introduction}

At the end of December 2019, COVID-19 appeared and threatened the health and lives of millions of people around the world. According to ongoing updates of the World Health Organization (WHO), COVID-19 has exceeded 23 million cases worldwide with more than 800,420 lives lost (as of August 23, 2020 WHO Coronavirus Disease (COVID-19) Dashboard). ${ }^{1}$ The WHO announcement of the 
pandemic status of COVID-19 instilled fear into populations throughout the world and horrified the global medical community only two-and-a-half months after the outbreak of the disease. ${ }^{2}$

COVID-19 is reported to be highly contagious with the possibility of causing severe respiratory disease, which progresses to severe fatal multisystem failures. ${ }^{3}$ The impact of COVID-19 extends to the multiple sectors of governments and public health systems. Accordingly, a public health emergency was declared at the national and international levels calling for the enacting of extraordinary measures to prevent the contagion and limit the outbreak. $^{3}$

After applying appropriate measures, the United Arab Emirates (UAE) successfully dealt with and controlled the spread of COVID-19. According to the Ministry of Health and Prevention (MOHAP) (2020) as of August 23, 2020, COVID-19 infections reached 67,007 confirmed cases with 58,488 cases recovered and 375 deaths. ${ }^{4}$

To stave off the pandemic, UAE public health authorities took action to protect the safety and well-being of citizens, residents, and visitors. Strict guidelines were imposed to control the spread of the disease as healthcare workers in hospitals prepared to deal with confirmed cases of COVID-19 patients in isolation units distributed in the specified hospitals across the country. 5,6

As the pandemic continued, the effects of COVID-19 were felt on the health, well-being, and economic stability of individuals, families, communities, and countries worldwide. $^{7}$ The risk of the pandemic problem lies in the unavailability of treatment, rapid outbreak, and the high possibility of human-to-human transmission. Therefore, prevention is still the best way to combat the disease. ${ }^{8}$ Thus, the WHO and Center for Disease Control and Prevention (CDC) announced recommendations to contain the infection including increasing public awareness, frequent washing of hands, using personal protective equipment, and admitting patients to quarantine in hospitals. ${ }^{9,10}$

Health-care professionals (HCPs), as the frontline caregivers dealing with infected patients, play a crucial role in limiting the outbreak of the disease by implementing safety and prevention practices. Otherwise they aggravate the problem, for example, it was reported that $0.3-20.9 \%$ of the Middle East Respiratory SyndromeCoronavirus (MERS-CoV) could arise among HCPs who have contact with infected patients. ${ }^{11}$ Another study reported that factors contributing to increasing numbers of cases of MERS and coronavirus included insufficient knowledge among HCPs of the diseases and lack of infection prevention and control measures in hospitals. ${ }^{12}$ This emphasizes that HCPs are at risk of being infected and spreading the disease, so they must adhere to the infection prevention and control guidelines. Studies revealed that HCPs' knowledge and attitudes affected their adherence to the required safety measures. $^{13,14}$

Questions arose exploring how well, or to what extent do HCPs who are assigned to take care of confirmed COVID-19 cases in hospitals are fully prepared with the knowledge, skills, attitudes, and self-preparedness. The international health-care system seemed to be caught off guard by COVID-19 without satisfactory preparations in any region of the world, including China, the first country to declare the high incidence and high mortality rate of COVID-19. Thus, a nursing research team from the Higher Colleges of Technology (HCT) with health-care experts from the MOHAP headquarters decided to conduct a hospital-based, national, multicenter study to assess the preparedness and responsiveness of hospital HCPs to care properly for COVID-19 patients. This study measures the awareness of hospital HCPs about the crisis and how they respond to limit and prevent further transmission. We believe that the information provided in this study will provide evidence to guide policy makers and health administrators on how best to guide clinical practice in the context of COVID-19 given its continuous existence; hence, to increase the awareness and preparedness of HCPs against COVID-19 at local, regional, and global levels. $^{3}$

\section{Study Purpose}

This study investigates the HCPs' general understanding the health risks of COVID-19 and to what extent they are equipped with the knowledge to protect themselves and others against COVID-19.

\section{Research Objectives}

(A) To assess the level of awareness, risk perception, and attitude of HCPs about COVID-19.

(B) To assess the extent of organizational measures taken to educate HCPs about COVID-19 threats.

(C) To identify the relationship between the organizational measures taken to educate HCPs and the awareness and perceptions of HCPs and ultimately, their compliance to COVID-19 safety measures. 


\section{Methodology \\ Study Design}

A cross-sectional design was utilized in this study. All MOHAP hospitals took part in the study via electronic survey. Participants responded to an electronic questionnaire posted on the UAE government electronic survey platform. This platform gives access to all HCPs registered in UAE governmental hospitals and ensures an equal chance for participation among all registered HCPs.

\section{Sample}

Participants were included in the study if they were HPCs 20 years of age or older, currently working at a MOHAP hospital, and able to read and write English. Hospital HCPs included registered nurses, physicians, pharmacists, respiratory therapists, laboratory technicians, and radiologists who worked in the Emergency Department Intensive Care Unit, Outpatient Department, Infectious Disease Clinic, Respiratory Disease Clinic, or any department designed to treat COVID-19 patients. HCPs who were on leave on the day of the survey were excluded. In this study, the authors ensure they have included participants from MOHAP affiliated hospitals who reside in almost all emirates in the country to maximize the generalizability of the results and allow for cross comparisons with other contexts.

\section{Sample Size Calculation}

The survey included 42 items in the questionnaire and the rule of thumb of having 10 subjects per each item, then a minimum of 400 participants would be needed to fulfill the study aims. Currently, the total number of HCPs in MOHAP hospitals is 8684. Indeed, the inclusion of responses from 941 HCPs exceeded the target considered satisfactorily proportionate to the total number of HCPs and help making the study results generalizable across the participating hospitals in the UAE to promote further studies of comparisons.

\section{Study Questionnaire}

The study tool comprised of a web-based questionnaire which was previously validated by Khader et al in another context and reported with modest evidence of reliable and valid results. ${ }^{15}$ Further, the study tool has gone through another review by health-care experts in MOHAP for feasibility and use in this study context. ${ }^{15}$ The survey was developed based on questions gleaned from a systematic review of literature and the international guidelines. $^{16-18}$

The questionnaire was designed in English and consisted of a questions relating to sociodemographic characteristics, the knowledge of nurses, and their attitudes and perceptions toward COVID-19 and infection control in MOHAP settings. The survey was a structured multiplechoice questionnaire divided into sections: demographic and profession-related characteristics; awareness of incubation period, the symptoms of the disease, the mode of transmission of COVID-19, and infection control measures for preventing COVID-19, HCPs attitude toward treating patients with COVID-19, and finally a section about preparedness of hospital HCPs about their confidence in providing care to confirmed cases with COVID-19.

\section{Data Collection Procedure and Ethical Approvals}

Upon approval from the Ethical Committee at MOHAP (approval reference no: MOHAP/DXB-REC/AAM/No.42/ 2020) and the Emirates Institutional Review Board for COVID-19 Research Committee (ref: DOH/CVDC/2020/ 1419), the electronic questionnaire was sent to MOHAP employees by the MOHAP study co-investigator who arranged with the concerned departments and obtained the necessary ethical approvals from MOHAP departments.

Data collection completed by MOHAP co-investigators under their guidance and following-up with different departments and groups. An online questionnaire using UAE government electronic survey platform that limits one-time participation per unique IP address. The survey questionnaire was anonymous, and participant identification numbers were used rather than any personal identifiers.

All the respondents of the survey completed a written informed consent embedded on the first page of the online questionnaire. If the participant answered "YES" to the first question of the form, he/she was automatically forwarded to the study questions page. Participation was completely voluntary and participants had the right to leave specific questions unanswered or withdraw from the survey any time if they felt uncomfortable answering any question. The collected electronic data remained confidential, and only authorized team members had access to it. In addition, data were completely encrypted and coded for use, mainly in statistical analysis using computer software. 


\section{Data Analysis}

Descriptive statistics performed, frequencies, percentages and chi-squared testing provided for the various items enclosed in the survey. The data on categorical variables are shown as $\mathrm{n}$ (\% of respondents) and the data on continuous variables is presented as mean and SD. The correlation and statistical comparison of the study variables was tested using Pearson's chi-squared test. In the entire study, $p$-values less than 0.05 were considered to be statistically significant. The entire data was statistically analyzed using Statistical Package for Social Sciences (SPSS v 22.0, IBM Corporation, Armonk, NY, USA) for MS Windows.

\section{Results}

\section{Participants' Demographics}

A total of 941 healthcare providers participated in the current study. The data presented in Table 1 shows that the majority of participants were female 754 (80.1\%). Their age ranged from $<30$ years old to $\geq 50$ years old with almost $50 \%$ of the respondents in the age bracket 31-39 years old. More than $50 \%(\mathrm{n}=551)$ of the participants have more than 10 years of experience. Almost half of the respondents $(n=525)$ were working at Sharjah. Four hundred and seventy-two (50.2\%) of the staff participants completed a study/residency program while the majority of the respondents $(80.9 \%)$ have infection control training. A total of $785(83.4 \%)$ received training pertaining to COVID-19, $402(42.7 \%)$ received rapid response team training RRT, and 489 (49.8\%) participated in response to disease outbreak.

\section{Participants' Knowledge About COVID-19}

Table 2 reflects the information obtained from respondents regarding their knowledge about COVID-19. When we asked about the symptoms of COVID-19, the majority of the respondents correctly reported fever (99\%), cough (98.5\%), sore throat $(93.7 \%)$ and shortness of breath (96.8\%). Red eyes and rash was reported by few respondents $34.2 \%$ and $29.1 \%$, respectively. Of the health-care providers who participated in the current study 852 (90.5\%) reported that patients with COVID-19 infection may be present without symptoms. When the participants were asked about the mode of transmission of COVID-19, the majority of them reported correctly.

According to COVID-19 testings, 922 (97.9\%) of participants correctly reported that real-time-polymerase chain reaction (RT-PCR) with respiratory material (nasopharyngeal or oropharyngeal swab/sputum/endotracheal
Table I Participants' Demographics $(n=94 I)$

\begin{tabular}{|c|c|}
\hline Variables & n (\%) \\
\hline \multicolumn{2}{|l|}{ Gender } \\
\hline Male & $187(19.9)$ \\
\hline Female & $754(80.1)$ \\
\hline \multicolumn{2}{|l|}{ Age } \\
\hline$<30$ years old & $105(11.2)$ \\
\hline $31-39$ years old & $420(44.6)$ \\
\hline $40-49$ years old & $281(29.9)$ \\
\hline$\geq 50$ years old & $135(14.3)$ \\
\hline \multicolumn{2}{|l|}{ Years of practice } \\
\hline$<5$ years & $145(15.4)$ \\
\hline $6-10$ years & $245(26)$ \\
\hline$>10$ years & $55 I(58.6)$ \\
\hline \multicolumn{2}{|l|}{ Region of practice } \\
\hline Abu Dhabi & $3(0.3)$ \\
\hline Ajman & $4(0.4)$ \\
\hline Dubai & $117(12.4)$ \\
\hline Fujairah & $15 \mid(16)$ \\
\hline Ras Al-Khaimah & $114(12.1)$ \\
\hline Sharjah & $525(55.8)$ \\
\hline Umm al-Quwain & $27(2.9)$ \\
\hline \multicolumn{2}{|l|}{ Working department } \\
\hline Emergency room & $113(12)$ \\
\hline Intensive care unit & $156(16.6)$ \\
\hline Ward & $168(17.9)$ \\
\hline Infectious disease clinic & $54(5.7)$ \\
\hline Respiratory disease clinic & $7(0.7)$ \\
\hline Others & $443(47.1)$ \\
\hline \multicolumn{2}{|l|}{$\begin{array}{l}\text { Completed a postgraduate study/residency } \\
\text { program }\end{array}$} \\
\hline Yes & $472(50.2)$ \\
\hline No & $469(49.8)$ \\
\hline \multicolumn{2}{|l|}{ Training in infection control } \\
\hline Yes & $761(80.9)$ \\
\hline No & $180(19.1)$ \\
\hline \multicolumn{2}{|l|}{ Training regarding COVID-19 } \\
\hline Yes & $785(83.4)$ \\
\hline No & $156(16.6)$ \\
\hline \multicolumn{2}{|l|}{ Received Rapid Response Team training (RRT) } \\
\hline Yes & $402(42.7)$ \\
\hline No & $539(57.3)$ \\
\hline \multicolumn{2}{|l|}{ Participated in response to disease outbreaks } \\
\hline Yes & $469(49.8)$ \\
\hline No & $472(50.2)$ \\
\hline
\end{tabular}

aspirate or bronchoalveolar lavage) test should be performed to diagnose COVID-19. When health-care providers were asked about aspects that should be considered to 
Table 2 Participants' Knowledge About COVID-19 (n=94I)

\begin{tabular}{|c|c|}
\hline Question & n (\%) \\
\hline $\begin{array}{l}\text { Which of the following are symptoms of the } \\
\text { COVID-19 infection? } \\
\text { - Fever } \\
\text { - Cough } \\
\text { - Runny nose } \\
\text { - Sore throat } \\
\text { - Shortness of breath } \\
\text { - Joint/muscle pain } \\
\text { - Red eyes } \\
\text { - Rash } \\
\text { - Diarrhea } \\
\text { - May present with no symptoms }\end{array}$ & $\begin{array}{l}934(99.2) \\
927(98.5) \\
656(69.7) \\
882(93.7) \\
911(96.8) \\
670(71.2) \\
322(34.2) \\
274(29.1) \\
799(84.9) \\
852(90.5)\end{array}$ \\
\hline $\begin{array}{l}\text { How can COVID-19 be transmitted? } \\
\text { - Via coughing and sneezing } \\
\text { - Hand shaking } \\
\text { - Touching surfaces as doorknobs and tables }\end{array}$ & $\begin{array}{l}931 \\
(98.9) \\
891 \\
886(94.6) \\
84.1)\end{array}$ \\
\hline $\begin{array}{l}\text { Which of the following tests should be } \\
\text { performed for the diagnosis of COVID-I9 } \\
\text { infection? } \\
\text { - Real-time-polymerase chain reaction (RT-PCR) with } \\
\text { respiratory material (nasopharyngeal or orophar- } \\
\text { yngeal swab/sputum/endotracheal aspirate or } \\
\text { bronchoalveolar lavage) } \\
\text { - Real-time PCR with serum sample } \\
\text { - Chest X-ray }\end{array}$ & $\begin{array}{l}446(47.3) \\
547(58.1)\end{array}$ \\
\hline $\begin{array}{l}\text { Which of the following should be considered at } \\
\text { high risk of having COVID-19? } \\
\text { - The presence of symptoms of diarrhea } \\
\text { - The presence of symptoms of a respiratory } \\
\text { infection } \\
\text { - History of travel to areas experiencing transmission } \\
\text { of COVID-19 } \\
\text { - History of contact with possible infected patients }\end{array}$ & $\begin{array}{l}304(32.3) \\
834(88.6) \\
821(87.2) \\
48(5.1)\end{array}$ \\
\hline $\begin{array}{l}\text { Which of the following measures should be } \\
\text { taken to prevent transmission from suspected } \\
\text { COVID-19 patients? } \\
\text { - Clean hands frequently by using alcohol-based hand } \\
\text { rub or soap and water } \\
\text { - Eat boiled and cooked food } \\
\text { - Put face mask on known or suspected patients } \\
\text { - Place known or suspected patients in adequately } \\
\text { ventilated single rooms } \\
\text { - Wear proper personal protective equipment (PPE) } \\
\text { - for all health-care providers } \\
\text { - Avoid moving and transporting patients out of their } \\
\text { - Clean and disinfect surfaces in contact with known } \\
\text { or suspected patients routinely }\end{array}$ & $\begin{array}{l}932(99) \\
494(52.4) \\
905(96.1) \\
759(80.6) \\
910(96.7) \\
840(89.2) \\
907(96.3)\end{array}$ \\
\hline
\end{tabular}

(Continued)
Table 2 (Continued).

\begin{tabular}{|l|l|}
\hline Question & n (\%) \\
\hline High-risk groups include: & \\
- Healthcare providers & $716(76.1)$ \\
- Elderly & $917(97.4)$ \\
- Male gender & $200(21.2)$ \\
- Children & $588(62.4)$ \\
- People with immune system deficiency & $922(97.9)$ \\
- Travelers & $630(66.9)$ \\
- People with chronic diseases & $913(97)$ \\
\hline There is a vaccine available for COVID-19 & \\
- Yes & $14(1.5)$ \\
- No & $927(98.5)$ \\
\hline Antibiotics are useful for the treatment of & \\
COVID-19 & \\
- Yes & $319(33.9)$ \\
- No & $622(66.1)$ \\
\hline In case of contact with suspected COVID-19 & \\
patients, do you know how to use personal & \\
protective equipment (PPE)? & \\
- Yes & \\
- No & $910(96.7)$ \\
\hline In case of contact with confirmed COVID-19 & \\
patients, do you know how to perform isolation \\
procedures on the patients to minimize chances \\
for exposure? & \\
- Yes & \\
- No & \\
\hline
\end{tabular}

identify patients at risk of having COVID-19, 834 (88.6\% $\%$ ) mentioned the presence of symptoms of a respiratory infection, $821(87.2 \%)$ mentioned history of travel to areas experiencing transmission of COVID-19, while 304 (32.3\%) and 48 (5.1\%) mentioned presence of symptoms with diarrhea and history of contact with possible infected patients, respectively, as risk factors of having COVID-19. In addition, the majority of the respondents correctly reported the measures that should be implemented to prevent the transmission of COVID-19.

When asked about the high-risk groups, respondents reported that the elderly, people with immune system deficiency, and people with chronic diseases are the most vulnerable with 917 (97.4\%), 922 (97.9\%), and 913 (97\%), respectively. The majority of respondents 927 (98.5\%) reported that up to now there is no vaccine available for COVID-19, while two thirds of the respondents $622(66.1 \%)$ reported that antibiotics are not useful in 
treating COVID-19. The vast majority of respondents 910 (96.7\%) reported that they know how to use personal protective equipment PPE while dealing with COVID-19 patients. Eight hundred and fifty-one (90.4\%) reported that they are familiar with the isolation procedures for COVID-19 patients.

When we asked respondents "to what extent do you have confidence in handling suspected COVID-19 patients," 402 (42.7\%) reported "to a considerable extent" and 319 (33.9\%) "to some extent". Nine hundred and fourteen $(97.1 \%)$ health-care providers who participated in the current study reported that PPE are useful in protecting themselves from a patient suspected to have COVID-19 patients, while 88.3 (93.8\%) reported "very important" that they need to change both masks and gloves regularly in order to decrease the possibility of transmitting infections to themselves and to patients.

\section{Participants' Source of Information About COVID-19}

Table 3 shows the information obtained from respondents regarding source of information about COVID-19. Nearly all participants $(\mathrm{n}=901,95.7 \%)$ reported they were updated with relevant information about COVID-19. Regarding the source of information pertaining to COVID-19, respondents reported that governmental organizations, such as MOHAP, were the main source $(\mathrm{n}=919,97.6 \%)$ while media and academic training courses were the second and third sources with 634 (67.3\%) and 604 (64.1\%), respectively.

\section{Participants' Risk Perception and Attitude Toward COVID-19}

The data presented in Table 4 shows that the majority of HCPs perceived COVID-19 as very dangerous $(n=60$, $64.2 \%)$ while $323(34.3 \%)$ reported it as moderately dangerous. When asked about how they perceived COVID-19, participants compared to SARS and MERS, almost two thirds reported both diseases are more dangerous 637 $(67.4 \%)$ and $634(67.4 \%)$ respectively, while 154 (16.4\%) and $158(16.8 \%)$ perceived it as less dangerous.

Almost 837 (88.9\%) HCPs believed that COVID-19 is a serious health problem. More than half of the respondents $(\mathrm{n}=549,58.3 \%)$ reported that COVID-19 symptoms were not resolved with time and did not require any special treatment while $392(41.7 \%)$ reported that COVID-19 symptoms were resolved with time and did not require any special treatment. The majority $(n=929$,
Table 3 Participants' Source of Information About COVID-19 $(n=94 I)$

\begin{tabular}{|c|c|}
\hline Question & n (\%) \\
\hline $\begin{array}{l}\text { Are you up to date on the latest information of } \\
\text { case definitions for COVID-19? } \\
\text { - Yes } \\
\text { - No }\end{array}$ & $\begin{array}{l}901(95.7) \\
40(4.3)\end{array}$ \\
\hline $\begin{array}{l}\text { What are your sources of information about the } \\
\text { COVID-19? } \\
\text { - Media (newspaper, television, radio, etc) } \\
\text { - Social network (Facebook, Twitter, blog, etc) } \\
\text { - Family members and friends } \\
\text { - Medical doctors or routinely visited physicians } \\
\text { - Academic training courses } \\
\text { - Colleagues } \\
\text { - Government organization such as Ministry of } \\
\text { Health and Prevention }\end{array}$ & $\begin{array}{l}634(67.3) \\
434(46.1) \\
229(24.3) \\
388(41.2) \\
604(64.1) \\
354(37.6) \\
919(97.6)\end{array}$ \\
\hline $\begin{array}{l}\text { To what extent do you have confidence in } \\
\text { handling suspected COVID-19 patients? } \\
\text { - Not at all } \\
\text { - To a little extent } \\
\text { - To some extent } \\
\text { - To a considerable extent } \\
\text { - To a great extent }\end{array}$ & $\begin{array}{l}49(5.3) \\
68(7.2) \\
103(10.9) \\
319(33.9) \\
402(42.7)\end{array}$ \\
\hline $\begin{array}{l}\text { Personal protective equipment such as face } \\
\text { shields, goggles, masks, and gloves are useful in } \\
\text { protecting myself from a patient suspected to } \\
\text { have COVID-19 patients. } \\
\text { - Yes } \\
\text { - No }\end{array}$ & $\begin{array}{l}914(97.1) \\
27(2.9)\end{array}$ \\
\hline $\begin{array}{l}\text { How important is changing both masks and } \\
\text { gloves in decreasing the possibility of } \\
\text { transmitting infections to myself and to patients? } \\
\text { - Very important } \\
\text { - Important } \\
\text { - Little important } \\
\text { - Not important }\end{array}$ & $\begin{array}{l}883(93.8) \\
52(5.5) \\
3(0.3)\end{array}$ \\
\hline
\end{tabular}

98.7\%) reported that it was important to educate people about COVID-19 to prevent the spread of the disease.

Regarding HCPs precautionary action in dealing with COVID-19 patients, nearly two thirds of respondents $(\mathrm{n}=650,69.1 \%)$ were willing to work with COVID-19 patients, while 291 (30.9\%) preferred to avoid working with a patient who is suspected of having COVID-19. In the case of COVID-19 patients sneezing or coughing, respondents reported different attitudes. For instance, 739 (78.5\%) mentioned that they would refer the patient to the attending physician and report symptoms, 473 (50\%) 
Table 4 Participants' Risk Perception and Attitude Toward COVID-19 (n=94I)

\begin{tabular}{|c|c|}
\hline Question & n (\%) \\
\hline $\begin{array}{l}\text { How do you perceive COVID-I9? } \\
\text { - Very dangerous } \\
\text { - Moderately dangerous } \\
\text { - Not dangerous }\end{array}$ & $\begin{array}{l}604(64.2) \\
323(34.3) \\
14(1.5)\end{array}$ \\
\hline $\begin{array}{l}\text { How do you perceive COVID-19 compared to } \\
\text { SARS? } \\
\text { - Less dangerous } \\
\text { - More dangerous } \\
\text { - The same }\end{array}$ & $\begin{array}{l}154(16.4) \\
637(67.7) \\
150(15.9)\end{array}$ \\
\hline $\begin{array}{l}\text { How do you perceive COVID-19 compared to } \\
\text { MERS? } \\
\text { - Less dangerous } \\
\text { - More dangerous } \\
\text { - The same }\end{array}$ & $\begin{array}{l}158(16.8) \\
634(67.4) \\
149(15.8)\end{array}$ \\
\hline $\begin{array}{l}\text { I believe COVID-19 is not currently a serious } \\
\text { public health issue. } \\
\text { - Yes } \\
\text { - No }\end{array}$ & $\begin{array}{l}104(11.1) \\
837(88.9)\end{array}$ \\
\hline $\begin{array}{l}\text { COVID-19 symptoms often resolve with time } \\
\text { and do not require any special treatment. } \\
\text { - Yes } \\
\text { - No }\end{array}$ & $\begin{array}{l}392(41.7) \\
549(58.3)\end{array}$ \\
\hline $\begin{array}{l}\text { Educating people about COVID-19 is important } \\
\text { to prevent the spread of the disease } \\
\text { - Yes } \\
\text { - No }\end{array}$ & $\begin{array}{l}929(98.7) \\
12(1.3)\end{array}$ \\
\hline $\begin{array}{l}\text { I prefer to avoid working with a patient who is } \\
\text { a suspect of COVID-19 } \\
\text { - Yes } \\
\text { - No }\end{array}$ & $\begin{array}{l}291(30.9) \\
650(69.1)\end{array}$ \\
\hline $\begin{array}{l}\text { In case a patient was sneezing or coughing, what } \\
\text { would you do? } \\
\text { - Refuse treating the patient and ask him/her to leave } \\
\text { the clinic } \\
\text { - Treat the patient and ask him/her to go to the } \\
\text { hospital } \\
\text { - Refer the patient to the hospital without treating } \\
\text { - him/her } \\
\text { - Refer the patient to the attending physician and } \\
\text { report symptoms }\end{array}$ & $\begin{array}{l}8(0.8) \\
473(50.2) \\
93(9.8) \\
739(78.5)\end{array}$ \\
\hline $\begin{array}{l}\text { I believe that asking patients to sit from } \\
\text { a distance, wear mask while in the waiting room, } \\
\text { and wash hands are: } \\
\text { - Necessary to help decreasing disease transmission } \\
\text { - Not necessary and could cause panic }\end{array}$ & $\begin{array}{l}938(99.7) \\
12(1.3)\end{array}$ \\
\hline
\end{tabular}

(Continued)
Table 4 (Continued).

\begin{tabular}{|l|l|}
\hline Question & n (\%) \\
\hline Would you allow a healthcare staff to work with & \\
patients if they have flu-like symptoms? & \\
- Yes & $225(23.9)$ \\
- No & $716(76.1)$ \\
\hline The role of healthcare staff in teaching others & \\
about COVID-19 is: & \\
- Very significant & $896(95.2)$ \\
- Moderately significant & $41(4.4)$ \\
- Mildly significant & $2(0.2)$ \\
- Not significant at all & $2(0.2)$ \\
\hline
\end{tabular}

mentioned that they treat the patient and ask him/her to go to the hospital, while $93(9.8 \%)$ refuse to treat the patient and refer him/her to the hospital.

A total of 939 (99.7\%) of HCPs believed that it was obligatory to ask patients to sit far from each other, wear masks in the waiting room, and wash hands to decrease disease transmission, while $12(1.3 \%)$ believed that this was not necessary and could cause panic. In addition, a total of $716(76.1 \%)$ reported that they would not allow any of their HCPs to work with patients if they have flulike symptoms. As a part of their educational role and disseminated knowledge, 896 (95.2\%) of respondents reported that their crucial role in teaching others about COVID-19 was very significant while 41 (4.4\%) reported it is moderately significant.

\section{Participants' Preparedness for COVID-19}

Table 5 describes the participants' preparedness to the COVID-19 outbreak, where the majority $(n=827,87.9 \%)$ of participants reported that they considered themselves prepared for the COVID-19 outbreak. On the same note, almost all of the participants $(\mathrm{n}=898,95.4 \%)$ reported that they considered the UAE prepared for the COVID-19 outbreak. As to the participants' satisfaction with the UAE preparedness to the COVID-19 outbreak, almost two thirds of the participants $(n=732,77.8 \%)$ have reported satisfaction with the UAE's preparedness to deal with the COVID-19 outbreak, while almost a quarter $(n=153,16.2 \%)$ of participants have reported their dissatisfaction with the UAE's preparedness in dealing with the COVID-19 outbreak. The majority of participants ( $\mathrm{n}=877$, 93.2\%) reported that they knew who to contact in case of an unprotected exposure to suspected COVID-19 patient 
Table 5 Participants' Preparedness to COVID-I9 (n=94I)

\begin{tabular}{|c|c|}
\hline Question & n (\%) \\
\hline $\begin{array}{l}\text { Do you consider yourself prepared for the } \\
\text { COVID-19 outbreak? } \\
\text { - Yes } \\
\text { - No }\end{array}$ & $\begin{array}{l}827(87.9) \\
114(12.1)\end{array}$ \\
\hline $\begin{array}{l}\text { Do you consider United Arab Emirates prepared } \\
\text { for the management of the COVID-19 outbreak? } \\
\text { - Yes } \\
\text { - No }\end{array}$ & $\begin{array}{l}898(95.4) \\
43(4.6)\end{array}$ \\
\hline $\begin{array}{l}\text { Please rate how satisfied you are with the } \\
\text { preparedness of United Arab Emirates to deal } \\
\text { with COVID-19 outbreak: } \\
\text { - Very unsatisfied } \\
\text { - Unsatisfied } \\
\text { - Neutral } \\
\text { - Satisfied } \\
\text { - Very satisfied }\end{array}$ & $\begin{array}{l}133(14.1) \\
20(2.1) \\
56(6) \\
391(41.6) \\
341(36.2)\end{array}$ \\
\hline $\begin{array}{l}\text { Do you know whom to contact in case there has } \\
\text { been an unprotected exposure to a suspected } \\
\text { COVID-19 patient? } \\
\text { - Yes } \\
\text { - No }\end{array}$ & $\begin{array}{l}877(93.2) \\
64(6.8)\end{array}$ \\
\hline $\begin{array}{l}\text { Do you know what to do if you have signs and/or } \\
\text { symptoms of COVID-19 infection? } \\
\text { - Yes } \\
\text { - No }\end{array}$ & $\begin{array}{l}914(97.1) \\
27(2.9)\end{array}$ \\
\hline
\end{tabular}

and what to do if they had signs and/or symptoms of COVID-19 infection ( $\mathrm{n}=914,97.1 \%$ ).

Table 6 shows the differences in frequency of participants' preparedness based on their demographics. A chisquared test of independence was performed to examine the relation between aging and participants' preparedness for the COVID-19 outbreak. The relation between the two variables was statistically significant, $\chi^{2}(3, \mathrm{n}=941)=10.6$, $p=0.01)$. Participants aged between 31 and 49 were more likely to consider themselves prepared for COVID-19 outbreak than younger or older participants. There was also a significant relation between the same age populations of between 31 and 49 and participants' consideration of the UAE's readiness to manage the COVID-19 outbreak and their satisfaction with the UAE's preparedness to the COVID-19 outbreak. The relation between the variables was significant, $\left.\chi^{2}(3, \mathrm{n}=941)=8.3, \mathrm{p}=0.04\right)$ and $\chi^{2}(12$, $\mathrm{n}=941)=34.1, p=0.001)$ respectively.

The participants who reported their satisfaction with the UAE's preparedness to deal with COVID-19 outbreak did differ by gender, where females were more likely to be satisfied with the UAE's preparedness to deal with the COVID-19 outbreak, $\left.\chi^{2}(4, \mathrm{n}=941)=13.1, p=0.011\right)$. It was also found that the participants' years of experience had a significant relation with participants preparedness for the COVID-19 outbreak, where the higher the experience the more prepared they were for COVID-19 outbreak, $\left.\chi^{2}(2, \mathrm{n}=941)=6.3, \mathrm{p}=0.04\right)$.

The relation between participants' training in an infection control unit and training about COVID-19 was also examined, with participants preparedness for the COVID19 outbreak and was found significant where participants who completed infection control training and COVID-19 training were more prepared for the COVID-19 outbreak, $\left.\chi^{2}(1, \mathrm{n}=941)=40.9, p<0.001\right)$, and $\chi^{2}(1, \mathrm{n}=941)=14.3$, $p<0.001$ ), respectively. It was also found that participants who had the COVID-19 training considered the UAE more prepared to manage the COVID-19 outbreak than participants who did not perform the COVID-19 training and were able to recognize the correct contact in case there was an unprotected exposure to a suspected COVID-19 patient, $\left.\chi^{2}(1, \mathrm{n}=941)=0.9, p=0.001\right)$ and $\chi^{2}(1, \mathrm{n}=941)$ $=6.6, p=0.01)$.

\section{Discussion}

COVID-19 is still a life-threatening infection spread worldwide and continues to be an international concern. A total of 23,025,622 infected cases and 800,420 deaths were reported globally as of August 23, 2020. In the UAE, a total number of 67,007 infected cases, 58,488 recovered cases, and 375 deaths were reported (as of August 23, 2020). ${ }^{4}$ Therefore, there is still a need to assess and improve hospital HCPs awareness and preparedness against COVID-19 in the UAE. Due to the crucial role of hospital HCPs in controlling and preventing the spread of COVID-19 outbreak, ${ }^{8,15,19,20}$ this research provides an insight into the level of awareness, perception, attitude, and self-preparedness of hospital HCPs against COVID-19 during the outbreak in the UAE, 2020. In this section, the significance of the study findings will be discussed and compared with the most recent studies.

The study findings show that the majority of hospital HCPs had the right level of knowledge towards the COVID-19 outbreak; this includes the infection symptoms, the mode of transmission, the diagnosis procedure, and the risk factors. Such a result is in line with previous studies. ${ }^{8,15,20}$ Knowing the symptoms helps hospital HCPs to recognize the threat and take the necessary actions and 
Table 6 Differences in Frequency of Participants' Preparedness Based on Their Demographics ( $n=94 \mathrm{I})$

\begin{tabular}{|c|c|c|c|c|c|c|c|c|c|c|c|c|c|}
\hline 更 & \multicolumn{3}{|c|}{$\begin{array}{l}\text { Do You Consider } \\
\text { Yourself Prepared } \\
\text { for the COVID-19 } \\
\text { Outbreak? }\end{array}$} & \multicolumn{3}{|c|}{$\begin{array}{l}\text { Do You Consider } \\
\text { United Arab } \\
\text { Emirates } \\
\text { Prepared for the } \\
\text { Management of } \\
\text { the COVID-I9 } \\
\text { Outbreak? }\end{array}$} & \multicolumn{4}{|c|}{$\begin{array}{l}\text { How Satisfied You are with the } \\
\text { Preparedness of UAE to Deal with COVID- } \\
19 \text { Outbreak? }\end{array}$} & \multicolumn{3}{|c|}{$\begin{array}{l}\text { Do You Know } \\
\text { Whom to Contact } \\
\text { in Case There Has } \\
\text { Been an } \\
\text { Unprotected } \\
\text { Exposure to } \\
\text { a Suspected } \\
\text { COVID-19 } \\
\text { Patient? }\end{array}$} \\
\hline Variables & Yes & No & $P$ & Yes & No & $P$ & $\begin{array}{l}\text { Very } \\
\text { Unsatisfied } \\
\text { and } \\
\text { Unsatisfied }\end{array}$ & Neutral & $\begin{array}{l}\text { Satisfied } \\
\text { and Very } \\
\text { Satisfied }\end{array}$ & $P$ & Yes & No & $P$ \\
\hline $\begin{array}{l}\text { Gender } \\
\text { Male } \\
\text { Female }\end{array}$ & $\begin{array}{l}171 \\
656\end{array}$ & $\begin{array}{l}16 \\
98\end{array}$ & 0.096 & $\begin{array}{l}179 \\
719\end{array}$ & $\begin{array}{l}8 \\
35\end{array}$ & 0.831 & $\begin{array}{l}31 \\
122\end{array}$ & $\begin{array}{l}5 \\
51\end{array}$ & $\begin{array}{l}151 \\
581\end{array}$ & $0.011^{*}$ & $\begin{array}{l}173 \\
704\end{array}$ & $\begin{array}{l}14 \\
50\end{array}$ & 0.678 \\
\hline $\begin{array}{l}\text { Age } \\
<30 \text { years old } \\
31-39 \text { years old } \\
40-49 \text { years old } \\
\geq 50 \text { years old }\end{array}$ & $\begin{array}{l}83 \\
37 \mid \\
248 \\
125\end{array}$ & $\begin{array}{l}22 \\
49 \\
33 \\
10\end{array}$ & $0.014^{*}$ & $\begin{array}{l}95 \\
400 \\
27 \mid \\
132\end{array}$ & $\begin{array}{l}10 \\
20 \\
10 \\
3\end{array}$ & $0.04 *$ & $\begin{array}{l}16 \\
70 \\
44 \\
23\end{array}$ & $\begin{array}{l}13 \\
28 \\
10 \\
5\end{array}$ & $\begin{array}{l}76 \\
322 \\
227 \\
107\end{array}$ & $0.00 I^{*}$ & $\begin{array}{l}95 \\
392 \\
262 \\
128\end{array}$ & $\begin{array}{l}10 \\
28 \\
19 \\
7\end{array}$ & 0.616 \\
\hline $\begin{array}{l}\text { Years of practice } \\
<5 \text { years } \\
6-10 \text { years } \\
>10 \text { years }\end{array}$ & $\begin{array}{l}119 \\
222 \\
486\end{array}$ & $\begin{array}{l}26 \\
23 \\
65\end{array}$ & $0.04 I^{*}$ & $\begin{array}{l}134 \\
237 \\
527\end{array}$ & $\begin{array}{l}11 \\
8 \\
24\end{array}$ & 0.133 & $\begin{array}{l}18 \\
44 \\
91\end{array}$ & $\begin{array}{l}14 \\
11 \\
31\end{array}$ & $\begin{array}{l}113 \\
190 \\
429\end{array}$ & 0.491 & $\begin{array}{l}129 \\
233 \\
515\end{array}$ & $\begin{array}{l}16 \\
12 \\
36\end{array}$ & 0.062 \\
\hline $\begin{array}{l}\text { Region of } \\
\text { practice } \\
\text { Abu Dhabi } \\
\text { Ajman } \\
\text { Dubai } \\
\text { Fujairah } \\
\text { Ras Al-Khaimah } \\
\text { Sharjah } \\
\text { Umm al-Quwain }\end{array}$ & $\begin{array}{l}1 \\
4 \\
100 \\
119 \\
104 \\
477 \\
22\end{array}$ & $\begin{array}{l}2 \\
0 \\
17 \\
32 \\
10 \\
48 \\
5\end{array}$ & $<0.001 *$ & $\begin{array}{l}2 \\
4 \\
112 \\
141 \\
110 \\
504 \\
25\end{array}$ & $\begin{array}{l}1 \\
0 \\
5 \\
10 \\
4 \\
21 \\
2\end{array}$ & 0.201 & $\begin{array}{l}2 \\
2 \\
22 \\
22 \\
22 \\
81 \\
2\end{array}$ & $\begin{array}{l}0 \\
0 \\
7 \\
14 \\
2 \\
33 \\
0\end{array}$ & $\begin{array}{l}1 \\
2 \\
88 \\
115 \\
90 \\
411 \\
25\end{array}$ & 0.153 & $\begin{array}{l}1 \\
4 \\
110 \\
135 \\
111 \\
492 \\
24\end{array}$ & $\begin{array}{l}2 \\
0 \\
7 \\
16 \\
3 \\
33 \\
3\end{array}$ & $<0.001^{*}$ \\
\hline $\begin{array}{l}\text { Completed } \\
\text { a postgraduate } \\
\text { study/residency } \\
\text { program } \\
\text { Yes } \\
\text { No }\end{array}$ & $\begin{array}{l}408 \\
419\end{array}$ & $\begin{array}{l}64 \\
50\end{array}$ & 0.173 & $\begin{array}{l}447 \\
45 I\end{array}$ & $\begin{array}{l}25 \\
18\end{array}$ & 0.284 & $\begin{array}{l}90 \\
63\end{array}$ & $\begin{array}{l}30 \\
26\end{array}$ & $\begin{array}{l}352 \\
380\end{array}$ & $0.013 *$ & $\begin{array}{l}430 \\
447\end{array}$ & $\begin{array}{l}42 \\
22\end{array}$ & $0.010 *$ \\
\hline $\begin{array}{l}\text { Training in } \\
\text { infection control } \\
\text { Yes } \\
\text { No }\end{array}$ & $\begin{array}{l}694 \\
133\end{array}$ & $\begin{array}{l}67 \\
47\end{array}$ & $<0.001 *$ & $\begin{array}{l}727 \\
171\end{array}$ & $\begin{array}{l}28 \\
15\end{array}$ & 0.758 & $\begin{array}{l}118 \\
35\end{array}$ & $\begin{array}{l}47 \\
9\end{array}$ & $\begin{array}{l}596 \\
136\end{array}$ & 0.446 & $\begin{array}{l}714 \\
163\end{array}$ & $\begin{array}{l}47 \\
17\end{array}$ & 0.117 \\
\hline $\begin{array}{l}\text { Training about } \\
\text { COVID-19 } \\
\text { Yes } \\
\text { No }\end{array}$ & $\begin{array}{l}704 \\
123\end{array}$ & $\begin{array}{l}81 \\
33\end{array}$ & $<0.001 *$ & $\begin{array}{l}757 \\
|4|\end{array}$ & $\begin{array}{l}28 \\
15\end{array}$ & $0.001 *$ & $\begin{array}{l}124 \\
29\end{array}$ & $\begin{array}{l}45 \\
11\end{array}$ & $\begin{array}{l}616 \\
116\end{array}$ & 0.47 I & $\begin{array}{l}739 \\
138\end{array}$ & $\begin{array}{l}46 \\
18\end{array}$ & $0.010 *$ \\
\hline
\end{tabular}

(Continued) 
Table 6 (Continued).

\begin{tabular}{|c|c|c|c|c|c|c|c|c|c|c|c|c|c|}
\hline Question & \multicolumn{3}{|c|}{$\begin{array}{l}\text { Do You Consider } \\
\text { Yourself Prepared } \\
\text { for the COVID-I9 } \\
\text { Outbreak? }\end{array}$} & \multicolumn{3}{|c|}{$\begin{array}{l}\text { Do You Consider } \\
\text { United Arab } \\
\text { Emirates } \\
\text { Prepared for the } \\
\text { Management of } \\
\text { the COVID-I9 } \\
\text { Outbreak? }\end{array}$} & \multicolumn{4}{|c|}{$\begin{array}{l}\text { How Satisfied You are with the } \\
\text { Preparedness of UAE to Deal with COVID- } \\
\text { I9 Outbreak? }\end{array}$} & \multicolumn{3}{|c|}{$\begin{array}{l}\text { Do You Know } \\
\text { Whom to Contact } \\
\text { in Case There Has } \\
\text { Been an } \\
\text { Unprotected } \\
\text { Exposure to } \\
\text { a Suspected } \\
\text { COVID-19 } \\
\text { Patient? }\end{array}$} \\
\hline Variables & Yes & No & $P$ & Yes & No & $P$ & $\begin{array}{l}\text { Very } \\
\text { Unsatisfied } \\
\text { and } \\
\text { Unsatisfied }\end{array}$ & Neutral & $\begin{array}{l}\text { Satisfied } \\
\text { and Very } \\
\text { Satisfied }\end{array}$ & $P$ & Yes & No & $P$ \\
\hline $\begin{array}{l}\text { Received Rapid } \\
\text { Response Team } \\
\text { training (RRT) } \\
\text { Yes } \\
\text { No }\end{array}$ & $\begin{array}{l}337 \\
450\end{array}$ & $\begin{array}{l}25 \\
89\end{array}$ & $<0.00 I^{*}$ & $\begin{array}{l}390 \\
508\end{array}$ & $\begin{array}{l}12 \\
31\end{array}$ & $0.044^{*}$ & $\begin{array}{l}69 \\
84\end{array}$ & $\begin{array}{l}16 \\
40\end{array}$ & $\begin{array}{l}317 \\
415\end{array}$ & $0.24 I$ & $\begin{array}{l}382 \\
495\end{array}$ & $\begin{array}{l}20 \\
44\end{array}$ & 0.055 \\
\hline $\begin{array}{l}\text { Participated in } \\
\text { response to } \\
\text { disease outbreaks } \\
\text { Yes } \\
\text { No }\end{array}$ & $\begin{array}{l}439 \\
388\end{array}$ & $\begin{array}{l}30 \\
84\end{array}$ & $<0.001 *$ & $\begin{array}{l}447 \\
45 I\end{array}$ & $\begin{array}{l}22 \\
21\end{array}$ & 0.859 & $\begin{array}{l}73 \\
80\end{array}$ & $\begin{array}{l}27 \\
29\end{array}$ & $\begin{array}{l}369 \\
363\end{array}$ & 0.7 & $\begin{array}{l}445 \\
432\end{array}$ & $\begin{array}{l}24 \\
40\end{array}$ & $0.04 I^{*}$ \\
\hline
\end{tabular}

Note: *P value is significant at $\leq 0.05$ using chi-squared test.

is considered essential in management ${ }^{21}$ and controlling the spread of COVID-19. ${ }^{17}$ This contradicted Bhagavathula et al's study that was conducted in the first week of March 2020, when COVID-19 had just become a global pandemic, it included 529 health-care workers globally. ${ }^{19}$ However, in the current study, there was a lack of knowledge regarding some of the risk factors that may indicate potential positive COVID-19, such as having diarrhea and contact with possible infected patients. This highlights the need to include such possible risk factors for positive COVID-19 in future training.

The current approach to COVID-19 is to control the source of infection; use appropriate preventive measures, and provide early diagnosis and isolation. ${ }^{22}$ This fact was reflected by the response of participants about preventive measures, as nearly all hospital HCPs were aware of the appropriate use of PPE, isolation procedures, and hand washing. The intensive training could have a primary influence on such a high level of knowledge. These findings are similar to the results of previous studies. ${ }^{15,19,20}$

The majority of the hospital HCPs in the current study were aware that patients with an immune system deficiency (97.9\%), elderly patients (97.4\%), and patients with chronic diseases (97\%) are at a higher risk of infection and mortality. This finding is in line with previous study findings in Vietnam. ${ }^{20}$ This elevated awareness plays an essential role in providing better prophylactic measures to reduce the risk of infection among these vulnerable groups. Moreover, the majority of the hospital HCPs were confident in handling patients with COVID19. This could be due to the thoughtful, quick response of intensive training that has been conducted by MOHAP for all hospital HCPs upon the COVID-19 outbreak. However, a considerable number of participants expressed low confidence in dealing with COVID-19confirmed cases; this could highlight the need for boosting training that targets such a group of mainly health-care teams.

The hospital HCPs have updated information about COVID-19 from different sources such as MOHAP, media, and academic training courses as such government organization source is considered a valuable resource for updated information and training for all hospital HCPs during this current pandemic. Such findings were reported 
by Huynh et al, with some difference regarding reporting social media. In this study the primary source of information followed by Ministry of Health in Vietnam (82.6\%), this indicates the need to update Ministry of Health website information regularly to encourage health-care workers to access this channel for all health-related issues and information. ${ }^{20}$ Similarly, in an Iranian study, credible websites, WhatsApp, and TV were the primary resources for COVID-19-related information. ${ }^{8}$ The nature of COVID-19 disease and its associated complications or impacts requires a trustworthy standardized source of information, especially among hospital HCPs who are in direct contact with confirmed cases of COVID-19.

The current study shows that hospital HCPs were aware that no vaccine or specific treatment for COVID19 is currently available; the treatment aims to reduce the symptoms without any specific antiviral medication for COVID-19. This result is similar to the study of Huynh et al, in which participants were aware of COVID-19 vaccine unavailability, and an antibiotic is not the appropriate treatment of COVID-19 (58.4\%) yet. ${ }^{20}$ Similarly, this finding was reported in a Jordanian study. ${ }^{15}$

In summary, the findings of our study show that female hospital HCPs from the middle age group 31 to 39; significantly considered themselves well prepared for COVID-19, and their satisfaction was high with the UAE's preparedness for the COVID-19 outbreak. Also, hospital HCPs with more clinical experience were significantly more prepared for the COVID outbreak and willing to care for confirmed cases of COVID-19.

The participants who have completed infection control and COVID-19 training considered themselves better prepared for COVID-19. These results pointed to the importance of an advanced and continued training education program about infection control and more specifically related to COVID-19 outbreaks and best ways to manage infection and control it. This is required as the WHO announced in different contexts that COVID-19 outbreaks might continue for a longer time than expected with no definite end, unfortunately.

\section{Strengths and Limitations}

Study limitations include having the inclusion criteria for MOHAP hospitals only which represent the federal healthcare system. Including different health-care settings at the multiple local government and the private sector would have made our study more comprehensive. Moreover, the results were not providing subgroup analyses, for hospital HCPs, such information could be useful to detect differences among the study subgroups, which might feed the research recommendations.

Nonetheless, the current study provides evidence about the preparedness of UAE hospital HCPs and their willingness to care for confirmed cases of COVID-19 having the required infection control training programs. To promote hospital HCPs' satisfaction and enhance positive attitudes toward caring for confirmed cases of COVID19 , administrators and policy makers have to maximize the effort put into staff training about COVID-19 to make them fully prepared for any future outbreaks should they occur as winter is approaching.

\section{Conclusion}

We conclude that HCPs have evidence-based understanding of the ways their own health is at risk while they are performing their duties in hospital setups. The study yields appropriate evidence that HCPs who undergo special infection control training and who are kept posted on the official updates on COVID-19 are more likely to remain vigilant at all times to keep themselves and their patients safe during the pandemic. Since the study tool has been validated by the health-care experts review in the Ministry of Health and Prevention, the findings shall be generalizable to the global health-care industry as everyone is in the same situation.

HCPs at MOHAP hospitals in the UAE were aware of COVID-19 symptoms, mode of transmission, infection control, and measures in health- care settings. Protocols and clinical guidelines related to COVID-19 best practices have to be standardized and shared across different health care settings in the UAE. This research reflected that providing educational training programs on infection control practices for COVID-19 across all health care professions have resulted in high compliance with infection control guidelines. Indeed, extending these educational programs for all HCPs including nonclinical and administrative staff could be a good practice to create more awareness.

Moreover, including health-care students from different programs would assist in improving knowledge. Preparing our future HCPs will result in more adherence to the guidelines and improve patient care and safety. In conclusion, to improve adherence to infection control practices to fight COVID19 this requires clear communication, effective leadership and management practices. 


\section{Acknowledgments}

Thanks to the MOHAP Hospital Sector administration and to all MOHAP hospital directors and HCPs who helped gather the study data. Extended thanks to all colleagues at nursing department-faculty of health sciences-HCT who helped in preparing the questionnaire and analyzing the data.

\section{Disclosure}

The authors reports no conflicts of interest in this work.

\section{References}

1. World Health Organization. WHO coronavirus disease (COVID-19) dashboard; 2020. Available from: https://covid19.who.int/. Accessed August 23, 2020.

2. Kim KH. COVID-19. Int Neurourol J. 2020;24(1):1. doi:10.5213/ inj.2020edi.001

3. World Health Organization. Coronavirus disease (COVID-19) pandemic; 2020. Available from: https://www.who.int/emergencies/ diseases/novel-coronavirus-2019. Accessed April 11, 2020.

4. Ministry of Health and Prevention. All you need to know about Coronavirus Disease (COVID-19); 2020. Available from: https:// www.mohap.gov.ae/en/Pages/default.aspx. Accessed April 13, 2020.

5. Abu Dhabi Public Health Center. Coronavirus disease (COVID-19); 2020. Available from: https://doh.gov.ae/en/covid-19. Accessed April 13, 2020.

6. Dubai Health Authority. Novel Coronavirus (COVID-19); 2020. Available from: https://www.dha.gov.ae/Covid19/Pages/home.aspx. Accessed April 13, 2020.

7. Torales J, O’Higgins M, Castaldelli-Maia JM, Ventriglio A. The outbreak of COVID-19 coronavirus and its impact on global mental health. Int J Soc Psychiatry. 2020;0020764020915212.

8. Nemati M, Ebrahimi B, Nemati F. Assessment of Iranian Nurses' knowledge and anxiety toward COVID-19 during the current outbreak in Iran. Arch Clin Infect Dis. 2020;15(COVID-19). doi:10.5812/archcid.102848

9. World Health Organization. Infection prevention and control during health care when novel coronavirus $(\mathrm{nCoV})$ infection is suspected: interim guidance; 2020. Available from: https://www.who.int/publica tions-detail/infectionprevention-and-control-during-health-care-when -novel-coronavirus-(ncov)-infection-issuspected-20200125. Accessed 13 April, 2020.

10. Centers for Disease Control and Prevention. Update and interim guidelines on outbreak of 2019 novel coronavirus (2019-nCoV); 2020. Available from: https://emergency.cdc.gov/han/han00427.asp. Accessed April 13, 2020.
11. Asaad AM, El-Sokkary RH, Alzamanan MA, El-Shafei M. Knowledge and attitudes towards Middle East respiratory syndrome-coronavirus (MERS-CoV) among health care workers in south-western Saudi Arabia. East Mediterr Health J. 2020;25..

12. Albarrak AI, Mohammed R, Al Elayan A, et al. Middle East Respiratory Syndrome (MERS): comparing the knowledge, attitude and practices of different health care workers. J Infect Public Health. 2019. doi:10.1016/j.jiph.2019.06.029

13. Modi PD, Nair G, Uppe A, et al. COVID-19 awareness among healthcare students and professionals in mumbai metropolitan region: a questionnaire-based survey. Cureus. 2020;12:4.

14. Zhong BL, Luo W, Li HM, et al. Knowledge, attitudes, and practices towards COVID-19 among Chinese residents during the rapid rise period of the COVID-19 outbreak: a quick online cross-sectional survey. Int J Biol Sci. 2020;16(10):1745. doi:10.7150/ijbs.45221

15. Khader Y, Al Nsour M, Al-Batayneh OB, et al. Dentists' awareness, perception, and attitude regarding COVID-19 and infection control: cross-sectional study among Jordanian dentists. JMIR Public Health Surveill. 2020;6(2):e18798. doi:10.2196/18798

16. American Dental Association. Coronavirus frequently asked questions; 2020. Available from: https://success.ada.org/en/practicemanagement/patients/coronavirus-frequently-asked-questions. Accessed March 26, 2020.

17. Meng L, Hua F, Bian Z. Coronavirus disease 2019 (COVID-19): emerging and future challenges for dental and oral medicine. J Dent Res. 2020;99(5):481-487. doi:10.1177/0022034520914246

18. World Health Organization. Clinical management of severe acute respiratory infection when COVID-19 is suspected; 2020. Available from: https://tinyurl.com/s23yv4p. Accessed March 13, 2020.

19. Bhagavathula AS, Aldhaleei WA, Rahmani J, Mahabadi MA, Bandari DK. Novel Coronavirus (COVID-19) knowledge and perceptions: a survey on healthcare workers. medRxiv. 2020. doi:10.1101/ 2020.03.09.20033381

20. Huynh G, Nguyen TN, Tran VK, Vo KN, Vo VT, Pham LA. Knowledge and attitude toward COVID-19 among healthcare workers at District 2 Hospital, Ho Chi Minh City. Asian Pac J Trop Med. 2020;13. doi:10.4103/1995-7645.280396

21. Gaffar BO, El Tantawi M, Al-Ansari AA, AlAgl AS, Farooqi FA, Almas KM. Knowledge and practices of dentists regarding MERS-CoV. A cross-sectional survey in Saudi Arabia. Saudi Med J. 2019;40(7):714-720. doi:10.15537/smj.2019.7.24304

22. Wang D, Hu B, Hu C, et al. Clinical characteristics of 138 hospitalized patients with 2019 novel coronavirus-infected pneumonia in Wuhan, China. JAMA. 2020. doi:10.1001/jama.2020.1585

\section{Publish your work in this journal}

The Journal of Multidisciplinary Healthcare is an international, peerreviewed open-access journal that aims to represent and publish research in healthcare areas delivered by practitioners of different disciplines. This includes studies and reviews conducted by multidisciplinary teams as well as research which evaluates the results or conduct of such teams or healthcare processes in general. The journal covers a very wide range of areas and welcomes submissions from practitioners at all levels, from all over the world. The manuscript management system is completely online and includes a very quick and fair peer-review system. Visit http://www.dovepress.com/testimonials. php to read real quotes from published authors. 